\title{
Peningkatan Minat dan Budaya Membaca Melalui Pelatihan Pengelolaan Perpustakaan Keluarga
}

\author{
Indah Kurnianingsih ${ }^{1 *}$, Rosini ${ }^{2}$, Sri Chusri ${ }^{3}$, Wardiyono ${ }^{4}$ \\ ${ }^{1,2,4}$ Program Studi Ilmu Perpustakaan Universitas YARSI Jakarta Pusat, DKI Jakarta 10510 \\ ${ }^{3}$ Program Studi Teknik Informatika Universitas YARSI Jakarta Pusat, DKI Jakarta 10510 \\ *indah.kurnianingsih@yarsi.ac.id
}

Submisi: 05 Februari 2018; Penerimaan: 05 April 2019

Kata Kunci:

Buku; Koleksi;

Perpustakaan

Keluarga; Pengelolaan

Keywords: Books;

Collection; Family

Home Library;

Management.
Abstrak Salah satu cara menginternalisasikan minat baca di lingkungan keluarga adalah dengan memiliki koleksi buku-buku keluarga yang disediakan di rumah sesuai karakteristik kebutuhan masing-masing anggota keluarga. Kepemilikian koleksi buku keluarga tersebut perlu dikelola agar fungsi dan tujuan perpustakaan keluarga sebagai sumber informasi dapat tercapai. Manfaat lain pengelolaan perpustakaan keluarga ini adalah kemudahan dalam mencari buku yang diinginkan. Ruang lingkup dari materi kegiatan pengabdian ini meliputi: strategi meningkatkan minat baca keluarga, ide-ide baru tentang konsep desain dan pemanfaatan ruang perpustakaan keluarga, cara mengolah dan merawat koleksi, serta demo pemanfaatan teknologi informasi dalam perpustakaan keluarga melalui open source SLiMS. Berdasarkan hasil evaluasi kegiatan pelatihan diperoleh hasil bahwa nilai rata-rata peserta dalam soal uji test terkait cara klasifikasi sederhana koleksi perpustakaan adalah adalah 83,8 dan terdapat 5 peserta mendapatkan nilai $100.72 \%$ peserta menunjukkan keinginan untuk menata dalam konsep perpustakaan keluarga yang nyaman dan menarik. Sebanyak $95 \%$ peserta menjawab pelatihan yang diberikan bermanfaat serta $98 \%$ peserta menjawab materi pelatihan ini relevan dengan kebutuhan peserta. Diharapkan pelatihan pengelolaan perpustakaan keluarga bagi pengurus dharma wanita kementrian keuangan republik Indonesia ini dapat semakin meluas untuk dilaksanakan di berbagai elemen masyarakat sebagai salah satu strategi dalam mewujudkan gerakan literasi dari keluarga.

Abstract One of the ways to internalize reading interest in the family is to have a book or resource collection at home designated to the needs of each family's member. These books collection need to be managed as a home library to fulfill the purpose as a source of information for the family. By managing this library, the collection can also be retrieved easily. The scope material in this engagement includes strategies to increase reading interest in the family, introducing new ideas of the design concept, and the use of home library space, practices in managing and maintaining the collection, and demo of SLiMS open source application utilization for home library. The evaluation results of the engagement showed that 83.8 percent of participant scored at average value in the test of a simple classification for library collection is. There are 5 participants get the score of $100.72 \%$ of participants indicate the desire and concern to organize and to create a comfortable and attractive home library. 95\% of participants valued the training provided as usefull and $98 \%$ of participants answered the training material is relevant to the needs of the participants. Furhter more, this Training of Family Library Management for Member of Dharma Wanita Finance Ministry Republic Indonesia can be applied by various elements of society as part of the strategies in developing awareness of the national spirit literacy movement from the family. 


\section{PENDAHULUAN}

Minat dan keterampilan membaca selayaknya dapat dimulai dari rumah. Keluarga yang memberikan perhatian khusus pada kegiatan membaca akan mewujudkan himpunan keluarga yang sadar kebutuhan informasi dan membentuk keluarga pembelajar sepanjang hayat. Orang tua memiliki peran penting dalam menumbuhkembangkan minat baca anak-anak sejak dini. Anak-anak yang sedari rumah sudah dibekali ilmu pengetahuan melalui buku-buku yang mereka baca akan memiliki wawasan yang lebih luas dan lebih siap untuk menerima proses pembelajaran di luar rumah, baik di sekolah maupun di masyarakat.

Salah satu cara untuk meningkatkan kemampuan literasi dasar di keluarga adalah dengan memiliki koleksi buku keluarga. Pada dasarnya banyak keluarga yang telah memiliki beberapa koleksi buku pribadi yang digunakan oleh anggota keluarga baik berupa buku teks ilmu pengetahuan maupun buku penunjang hobi dan minat. Namun berbagai koleksi buku pribadi tersebut belum dikelola dengan baik, sehingga menyebabkan beberapa kerugian, diantaranya koleksi yang hilang, rusak, dan sulit dicari. Oleh sebab itu diperlukan manajemen pengelolaan perpustakaan yang menarik, sehingga dapat semakin meningkatkan pemanfaatan dan kenyamanan di perpustakaan keluarga yang dimiliki. Kepemilikan koleksi buku-buku keluarga ini perlu dikelola agar terorganisir dan semakin meningkatkan minat baca di lingkungan sekitar.

\subsection{Peran Orang Tua Dalam Mengembangkan Minat Baca}

Berbagai hasil riset menyatakan bahwa kebiasaan membaca seorang anak akan mempengaruhi hasil akademik di sekolah. Kebiasaan membaca tersebut dapat membantu anak-anak dalam mengembangkan pemikiran kritis dan keterampilan analisis. Melalui membaca maka perbendaharaan kosakata anak-anak akan semakin banyak. Baker, 
Scher, \& Mackler (1997) menyatakan bahwa budaya literasi dari rumah akan mendorong motivasi dan minat membaca bagi anak-anak. Mereka akan lebih banyak merasakan kenikmatan dalam membaca. Hal ini menjadi perhatian bagi para orang tua untuk melibatkan program literasi sejak dari lingkungan rumah dan keluarga.

Chen (2008) menegaskan bahwa rumah yang menyediakan suasana yang kaya dengan aspek literasi akan membuat anak-anak menghabiskan waktu lebih banyak untuk membaca dibandingkan dengan anak-anak yang kekurangan sumber bahan bacaan. Menurut Bano, Jabeen, \& Qutoshi (2018) orangtua sebagai guru pertama di rumah harus memainkan peran aktif dalam mendorong kebiasaan membaca antara lain dengan menyediakan bahan bacaan di lingkungan di rumah serta penyediaan sudut baca di rumah dapat menjadi salah satu strategi efektif dalam mendorong minat anak-anak terhadap kegiatan membaca. Orang tua memiliki tanggung jawab untuk menjamin anak-anaknya mendapatkan lingkungan pendidikan dari rumah yang dapat mendukung kegiatan anakanak di sekolah.

\subsection{Peranan Perpustakaan Keluarga}

Perpustakaan keluarga adalah perpustakaan yang ditujukan dan digunakan dalam ruang lingkup yang kecil. Salah satu contohnya dalah perpustakaan keluarga. Keberadaan perpustakaan keluarga dalam lingkungan keluarga berfungsi untuk penyimpanan koleksi keluarga agar terjaga dengan baik, menyediakan berbagai informasi yang dibutuhkan oleh anggota keluarga, fungsi hiburan dengan mengakses berbagai sumber informasi menarik, dan fungsi norma serta kultural dengan menanamkan nilai-nilai, norma dan budaya kepada seluruh anggota keluarga.

Huriyah (2016) menyatakan bahwa perpustakaan keluarga bisa menjadi sarana yang paling tepat untuk memenuhi kebutuhan keluarga dalam penyediaan bahan bacaan 
karena disesuaikan dengan minat spesifik anggota keluarga. Selain itu, perpustakaan keluarga juga menjadi alternatif menghabiskan waktu. Beberapa manfaat yang dapat diperoleh dengan adanya perpustakaan keluarga, antara lain: (a) mengenalkan pada anak atau anggota keluarga tentang bahan bacaan yang mengandung ilmu pengetahuan maupun rekreasi; (b) menanamkan sikap saling membantu seluruh anggota keluarga dalam proses pembelajaran di rumah; (c) mengajar anak untuk menghargai bahan bacaan; (d) bisa dijadikan ajang mempererat kebersamaan dalam keluarga; dan (e) dapat menggugah minat baca anggota keluarga dan menciptakan kehangatan keluarga.

Selain itu, seiring dengan perubahan zaman dan perkembangan teknologi informasi, anak-anak dibanjiri oleh berbagai media hiburan. Hal tersebut menyebabkan kenikmatan membaca menjadi sulit dirasakan dengan adanya perubahan sosial yang terjadi. Keluarga sebagai unit terkecil di masyarakat harus dapat menanamkan kebiaasaan membaca kepada anak sejak dini Farida (2001).

\subsection{Membangun Perpustakaan Keluarga}

Faktor-faktor yang perlu diperhatikan dalam membangun perpustakaan keluarga yang ideal antara lain: (a) penyediaan fasilitas baik berupa perabot maupun audio visual untuk membangun perpustakaan keluarga yang ideal; (b) penyediaan bahan bacaan yang sesuai dengan kebutuhan keluarga; dan (c) penataan kondisi fisik (athmospheric) perpustakaan keluarga dengan melibatkan semua anggota dalam keluarga yang merupakan pengguna utama dari perpustakaan.

Tujuan dan sasaran pembangunan perpustakaan yang ideal adalah menciptakan kondisi perpustakaan yang kondusif, nyaman, indah dan memiliki nilai-nilai estetika sehingga diharapkan dengan kondisi tersebut menimbulkan kegairahan seluruh anggota keluarga memanfaatkan sumber daya yang ada dengan tenang dan nyaman serta mampu 
memberikan kepuasan kepada seluruh anggota keluarga. Adapun penataan fisik meliputi: (a) penentuan lokasi; (b) perancangan desain; (c) pencahayaan/penerangan; (d) penataan sirkulasi udara; dan (e) penataan elemen dekoratif (Santoso, 2011).

Perpustakaan keluarga yang baik dan efisien adalah perpustakaan yang menyediakan sumber-sumber informasi bagi pembahasan dan pemecahan berbagai persoalan. Selain itu, dapat bermanfaat sebagai referensi pengerjaan tugas anak-anak di sekolah. Perpustakaan juga baiknya memuat buku-buku untuk tingkatan yang beragam, juga buku-buku yang cocok untuk orang dewasa dan anak-anak, laki-laki dan perempuan.

Salah satu cara untuk meningkatkan kemampuan dan minat membaca dimulai dengan menciptakan lingkungan yang kondusif terhadap akses sumber informasi yang dibutuhkan, khususnya bagi keluarga yang masih memiliki anak usia sekolah dan remaja. Walaupun banyak keluarga yang sudah memiliki koleksi buku pribadi namun tidak banyak keluarga yang telah mengelola koleksi buku keluarganya tersebut dengan baik. Beberapa kerugian yang diakibatkan dari kurangnya pengelolaan perpustakaan di rumah diantaranya adalah koleksi yang hilang, rusak, dan sulit dicari. Oleh sebab itu diperlukan manajemen pengelolaan perpustakaan yang menarik sehingga dapat semakin meningkatkan pemanfaatan dan kenyamanan di perpustakaan keluarga yang dimiliki.

Berdasarkan permasalahan yang timbul dalam pengelolaan koleksi buku, kegiatan pelatihan Pengelolaan Perpustakaan Keluarga Berbasis TI akan sangat bermanfaat bagi para peserta, yaitu Ibu-Ibu Pengurus Dharma Wanita. Pelatihan ini berupa pengelolaan koleksi keluarga, perancangan ruang dan tata letak perpustakaan keluarga yang menarik, sehingga koleksi keluarga yang dimiliki terawat, mudah ditemukan untuk digunakan dalam mengerjakan tugas, dan rekreasi hiburan dengan nyaman. 
Tujuan dari kegiatan pengabdian ini antara lain (a) memotivasi ibu-ibu dharma wanita yang belum memiliki perpustakaan keluarga agar memiliki perpustakaan keluarga; (b) memberikan bekal keterampilan dalam pengelolaan koleksi-koleksi buku keluarga; (c) memberikan ide-ide baru tentang konsep desain pemanfaatan ruang keluarga sebagai perpustakaan keluarga; dan (d) memberikan pengetahuan tentang perkembangan otomasi di bidang pepustakaan melalui demo pemanfaatan teknologi informasi dalam perpustakaan keluarga melalui open source SLiMS.

\section{METODE PELAKSANAAN}

Metode kegiatan pengabdian dilakukan dengan memberikan pelatihan manajemen perpustakaan tingkat dasar beserta pratik penyusunan koleksi buku keluarga sesuai dengan kebutuhan. Materi pelatihan disesuaikan dengan kebutuhan para peserta agar dapat menjawab berbagai permasalahan pengelolaan perpustakaan keluarga (Tabel 1).

\section{Tabel 1. Topik Materi Pelatihan}

\begin{tabular}{lll}
\hline No & Topik & Metode \\
\hline 1 & Strategi Minat Baca di Keluarga & Pemutaran film, refleksi, \& diskusi \\
2 & Sistem Klasifikasi Koleksi Sederhana & Presentasi dan Praktik \\
& Uji Tes & \\
3 & Desain dan Tata Ruang Perpustakaan Keluarga & Presentasi \\
4 & Pemanfaatan SLiMS dalam Perpustakaan & Demo \\
& Keluarga & \\
& Evaluasi Kegiatan & \\
\hline
\end{tabular}
Sumber: Data primer diolah (2018)

Adapun evaluasi kegiatan pengabdian dilakukan melalui uji tes dan kuesioner. Uji tes berupa beberapa soal terkait cara pengelompokkan sederhana koleksi perpustakaan masing-masing keluarga. Uji tes ini diberikan setelah materi dasar klasifikasi kolekasi diberikan. Adapun kuesioner berisi beberapa pertanyaan untuk menggali motivasi peserta, apakah setelah mengikuti kegiatan ini menunjukkan keinginan untuk menata dalam konsep perpustakaan keluarga yang nyaman dan menarik. 


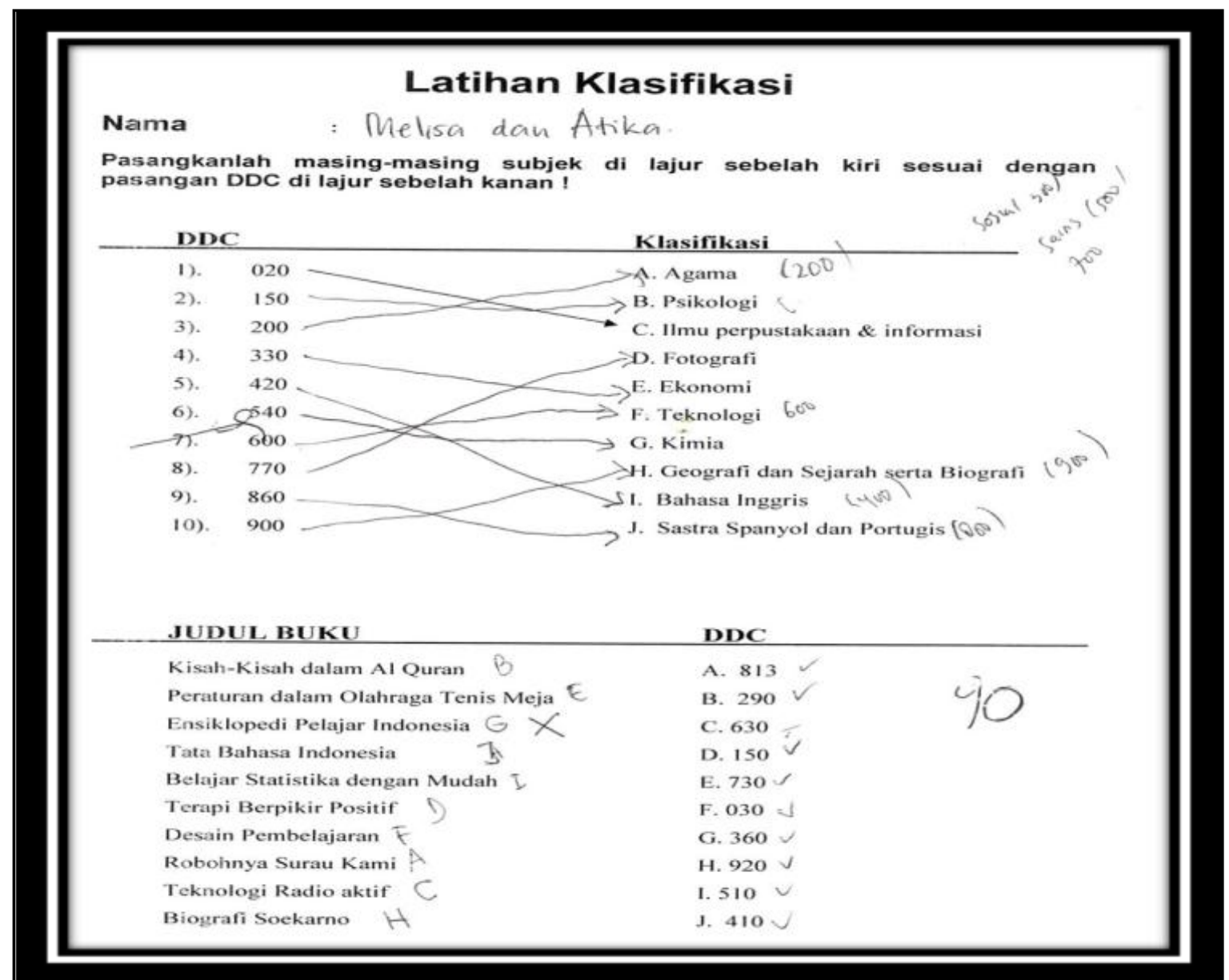

Sumber: Data primer diolah (2018)

Gambar 1. Contoh Hasil Tes Klasifikasi Buku Sederhana

\section{HASIL DAN PEMBAHASAN}

kegiatan pengabdian pelatihan pengelolaan perpustakaan keluarga berbasis Teknologi Informatika (TI) bagi anggota dan pengurus dharma wanita Kemenkeu ini diikuti oleh 54 orang peserta. Peserta terdiri dari anggota dan pengurus dari semua Bidang di DWP Kementerian Keuangan. Para peserta tersebut adalah mereka yang memiliki ketertarikan pada pengembangan minat baca di keluarga dan masyarakat. Para peserta yang hadir telah memiliki beberapa koleksi buku keluarga namun belum mengelola dan mengatur koleksi keluarganya tersebut secara sistematis. 
Pada saat pertengahan kegiatan, tepatnya setelah peserta mendapatkan materi tentang klasifikasi koleksi sederhana peserta diberika soal untuk menguji kemampuan penyerapan materi. Soal dikerjakan secara berkelompok, masing-masing kelompok terdiri dari 2-3 orang.

Berdasarkan hasil evaluasi kegiatan pelatihan (Tabel 2) diperoleh hasil bahwa nilai rata-rata peserta dalam soal uji test terkait cara klasifikasi sederhana koleksi perpustakaan adalah 83,8 dan terdapat 5 kelompok yang mendapatkan nilai 100. Hal ini rata-rata peserta menunjukkan kemampuan yang baik dalam mengerjakan soal uji tes klasifikasi sederhana

\section{Tabel 2. Hasil Uji Test Klasifikasi Sederhana}

\begin{tabular}{rccc}
\hline Nama & Soal A & Soal B & Nilai Total \\
\hline Kelompok 1 & 90 & 70 & 80 \\
Kelompok 2 & 90 & 80 & 85 \\
Kelompok 3 & 80 & 60 & 70 \\
Kelompok 4 & 70 & 80 & 75 \\
Kelompok 5 & 100 & 100 & 100 \\
Kelompok 6 & 80 & 80 & 80 \\
Kelompok 7 & 80 & 70 & 75 \\
Kelompok 8 & 100 & 100 & 100 \\
Kelompok 9 & 60 & 60 & 60 \\
Kelompok 10 & 100 & 100 & 100 \\
Kelompok 11 & 70 & 50 & 60 \\
Kelompok 12 & 100 & 100 & 100 \\
Kelompok 13 & 100 & 80 & 90 \\
Kelompok 14 & 100 & 100 & 100 \\
Kelompok 15 & 100 & 80 & 90 \\
Kelompok 16 & 80 & 70 & 75 \\
Kelompok 17 & 80 & 80 & 80 \\
Kelompok 18 & 90 & 90 & 90 \\
\hline Rata-Rata & & & $\mathbf{8 3 , 8}$ \\
\hline
\end{tabular}

Sumber: Data primer diolah (2018)

\subsection{Opini Peserta Tentang Penanaman Budaya Literasi}

Di sesi pertama peserta diberikan materi wawasan tentang pentingnya "Reading Nation" harus dimiliki oleh Bangsa Indonesia yaitu seuatu bangsa yang memiliki budaya dan 
minat baca yang tinggi agar dapat berkompetisi di era global. Keluarga memiliki peran utama dalam mendorong minat baca para anggota keluarga. Pada sesi ini dipaparkan pula tentang dampak teknologi informasi terhadap budaya literasi membaca dan menulis anak-anak Indonesia serta data terbaru tingkat literasi anak-anak Indonesia saat ini. Hal ini diberikan untuk menyadarkan masyarakat bahwa penanaman budaya literasi tidak hanya menjadi tanggung jawab sekolah namun juga rumah sebagai "sekolah" pertama dalam mewujudkan budaya literasi.

Pertanyaan 1:

Penanaman nilai-nilai dan keterampilan literasi membaca dan menulis tidak hanya tanggung jawab sekolah. Namun Penanaman nilai-nilai dan keterampilan literasi membaca dan menulis berawal dari "rumah". Bagaimana pendapat Ibu dengan pernyataan di atas?

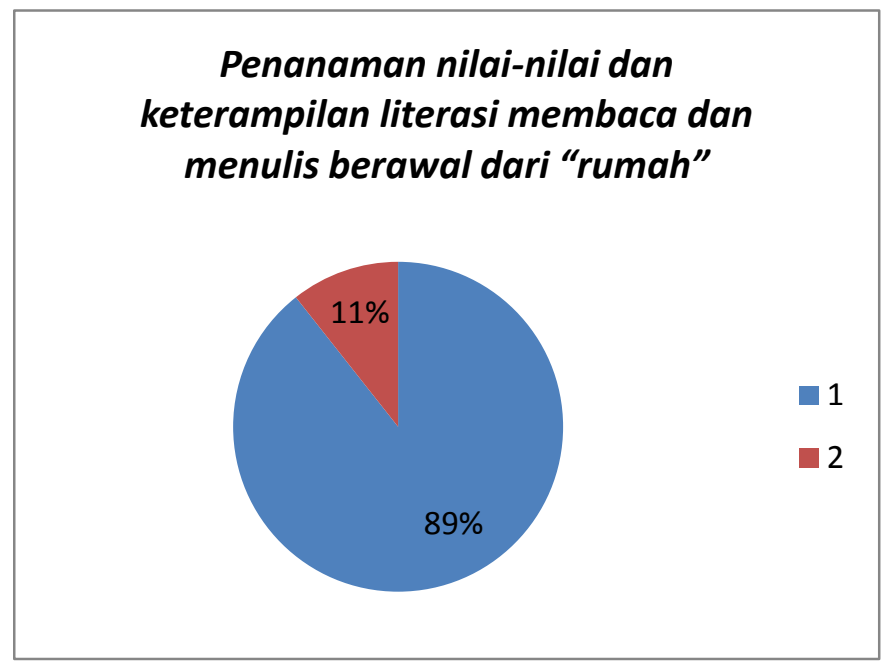

Sumber: Data primer diolah (2018)

Gambar 2. Opini Peserta Tentang Penanaman Budaya Literasi

Sebanyak $89 \%$ peserta menyatakan sangat setuju dan $11 \%$ menyatakan setuju bahwa penanaman nilai-nilai dan keterampilan literasi membaca dan menulis berawal dari rumah. Hal ini dapat disimpulkan bahwa seluruh peserta telah sepakat penanaman budaya 
membaca dan menulis bisa ditanamkan sejak dini di lingkungan keluarga dan bukan hanya tanggung jawab lingkungan sekolah (Gambar 2).

\subsection{Pengelolaan Perpustakaan keluarga}

Pertanyaan 2:

Setelah mengikuti kegiatan ini apakah Ibu termotivasi untuk mengelola dan menata berbagai koleksi sumber informasi (Buku, e-book, majalah, ensiklopedia, dll) yang tersedia di rumah?

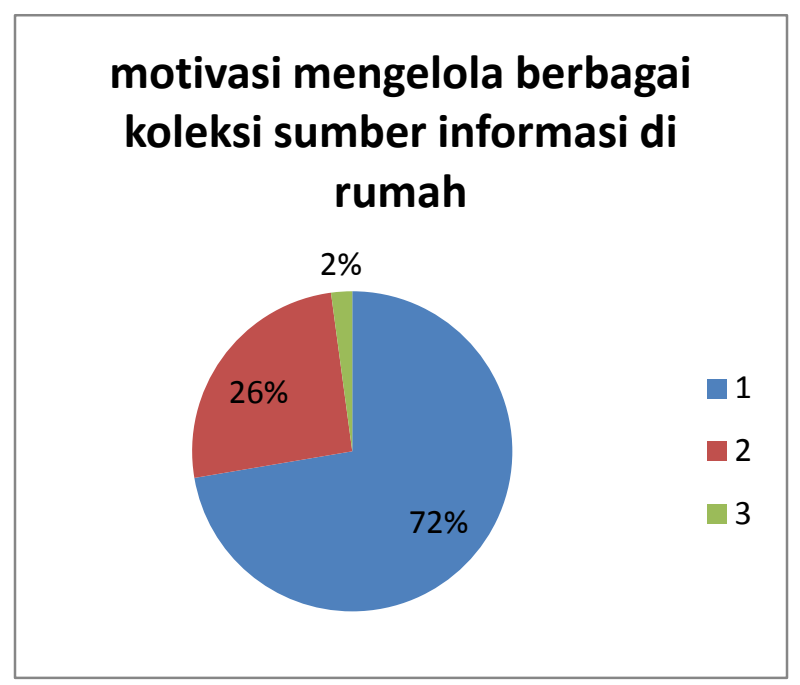

Sumber: Data primer diolah (2018)

Gambar 3. Motivasi Mengelola Berbagai Koleksi Sumber Informasi di Rumah

Sebesar $72 \%$ peserta merasa termotivasi untuk mengelola berbagai koleksi sumbersumber informasi yang ada di keluarga baik dalam bentuk buku, e-book, majalah, dan ensiklopedia yang nyaman dan menarik. Adapun $26 \%$ peserta menjawab ada kemungkinan, serta 2\% menjawab tidak (Gambar 3). $72 \%$ peserta atau sekitar 39 orang yang menjawab "Ya" kemudian diminta untuk menganalisa kondisi rumah masing-masing dan menyampaikan gambaran terkait tata letak dan ruang dalam mewujudkan perpustakaan keluarga sesuai dengan karakteristik keluarga masing-masing. Pertanyaan ke 3: 
Jika ya, mohon Ibu dapat menjelaskan ide/gagasan untuk mewujudkan salah satu sudut ruangan di rumah Ibu masing-masing untuk difungsikan sebagai perpustakaan keluar$g a$

Variasi jawaban dari gagasan peserta untuk mewujudkan perpustakaan keluarganya masing-masing ditampilkan dalam Tabel 3.

Tabel 3. Gagasan Peserta Tentang Ide Ruangan di Rumah Sebagai Tempat Perpustakaan Keluarga

\begin{tabular}{llll}
\hline No & Gagasan & No & Gagasan \\
\hline 1 & Disebelah tempat tidur & 16 & ruang khusus tersendiri \\
2 & rak diatas dinding & 17 & memanfaatkan ruang bawah tangga \\
3 & atas lemari kecil & 18 & ruang khusus dengan mushola \\
4 & lemari khusus buku-buku & 19 & rak dinding \\
5 & ruang khusus perpustakaan & 20 & mengatur buku di kosan \\
6 & sudah ada ruang tersendiri & 21 & memanfaatkan bagian rumah yang \\
& & & memadai \\
7 & perpustakaan sederhana & 22 & Disebelah tempat tidur \\
8 & ingin membuat ruangan & 23 & lemari kecil diisi buku \\
9 & lemari kosong untuk buku & 24 & di sudut ruang keluarga \\
10 & mendata buku & 25 & sudah ada rak khusus, kurang katalog \\
11 & rak di dinding & 26 & ruang kosong \\
12 & dimulai dengan family reading day & 27 & sudah ada rak buku \\
13 & membuat sudut kecil utk baca & 28 & ruang keluarga \\
14 & memanfaatkan ruang kosong & 29 & menyimpan buku pelajaran anak \\
15 & lemari nganggur & 30 & penataan buku yang menarik \\
\hline
\end{tabular}

Sumber: Data primer diolah (2018)

\subsection{Pengelolaan Perpustakaan yang Melibatkan Teknologi Informasi}

Pertanyaan ke 4:

Menurut Ibu, perlukah pengelolaan perpustakaan keluarga menggunakan teknologi informasi? 


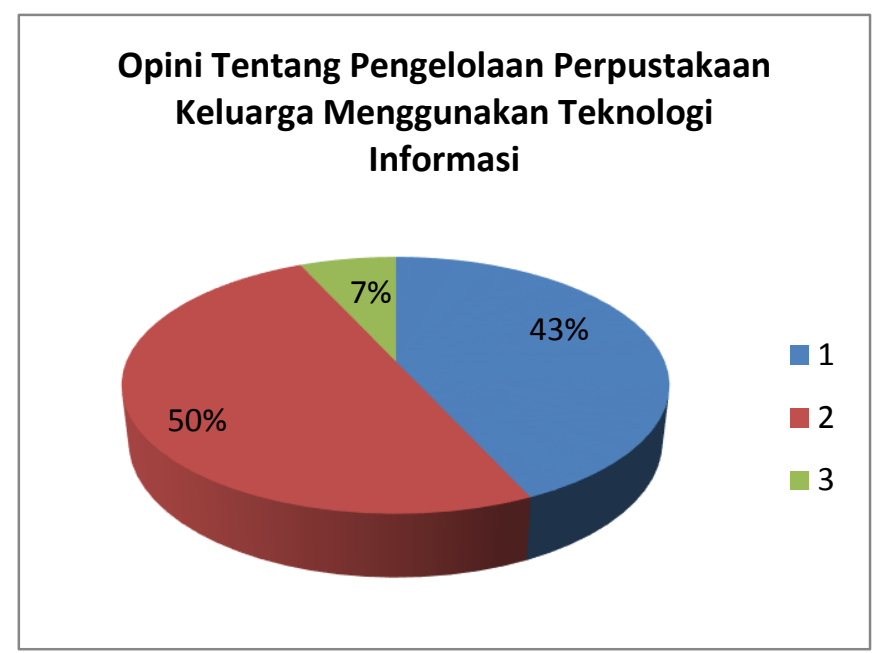

Sumber: Data primer diolah (2018)

Gambar 4. Opini Tentang Otomasi Perpustakaan Keluarga

Sebesar $43 \%$ peserta atau sekitar 23 orang menjawab sangat perlu, 50\% atau sekitar 27 orang menjawab perlu, dan $7 \%$ atau sekitar 4 orang menjawab kurang perlu. Dapat disimpulkan sebagian besar peserta menyatakan setuju jika pengelolan perpustakaan keluarga memerlukan fasilitas teknologi informasi agar mempermudah pengelolaannya (Gambar 4).

Peserta didemonstrasikan salah satu Open Source aplikasi otomasi perpustakaan yaitu SLiMS. SLiMS merupakan perangkat lunak manajemen perpustakaan yang terintegrasi dan menyediakan banyak fitur pendukung kegiatan di perpustakaan. Fitur-fitur ini meliputi pengelolaan data deskripsi koleksi bibliografi, penelusuran OPAC (online public access catalog), manajemen keanggotan pperpustakaan, layanan peminjaman/sirkulasi buku, pembuatan laporan, pemeliharan koleksi, dan masih banyak lagi. SLiMS merupakan pilihan menarik bagi banyak perpustakaan keluarga untuk membantu dalam pengelolaan layanan perpustakaan keluarga yang lebih baik lagi.

Peserta juga ditunjukkan SLiMS mobile berbasis android yang bernama SLiMS less (Gambar 5 dan Gambar 6). Hal ini dimaksudkan untuk menginformasikan kepada peserta akan mudahnya aplikasi SliMS yang bisa dimanfaatkan dari ponsel genggam masing-masing peserta. 


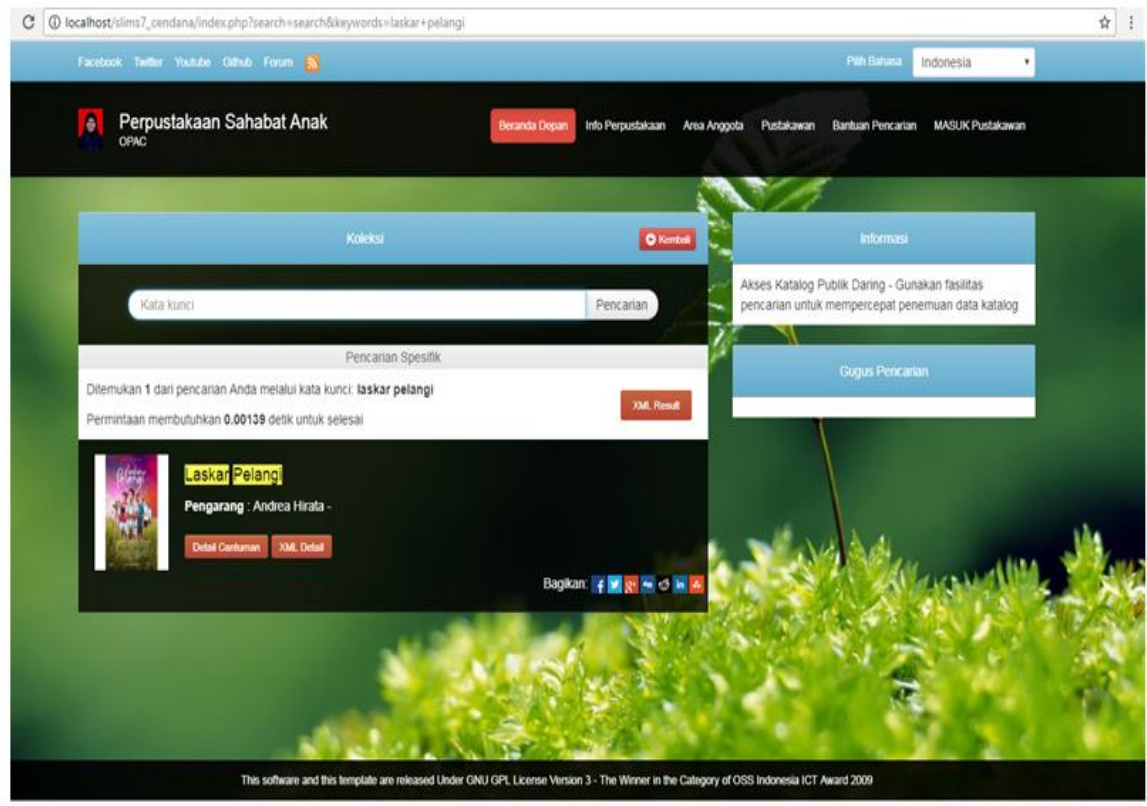

Sumber: Data primer diolah (2018)

Gambar 5. Otomasi Perpustakaan Berbasis SLiMS: Mengakomodir Pengelolaan Koleksi Digital: $e$-book

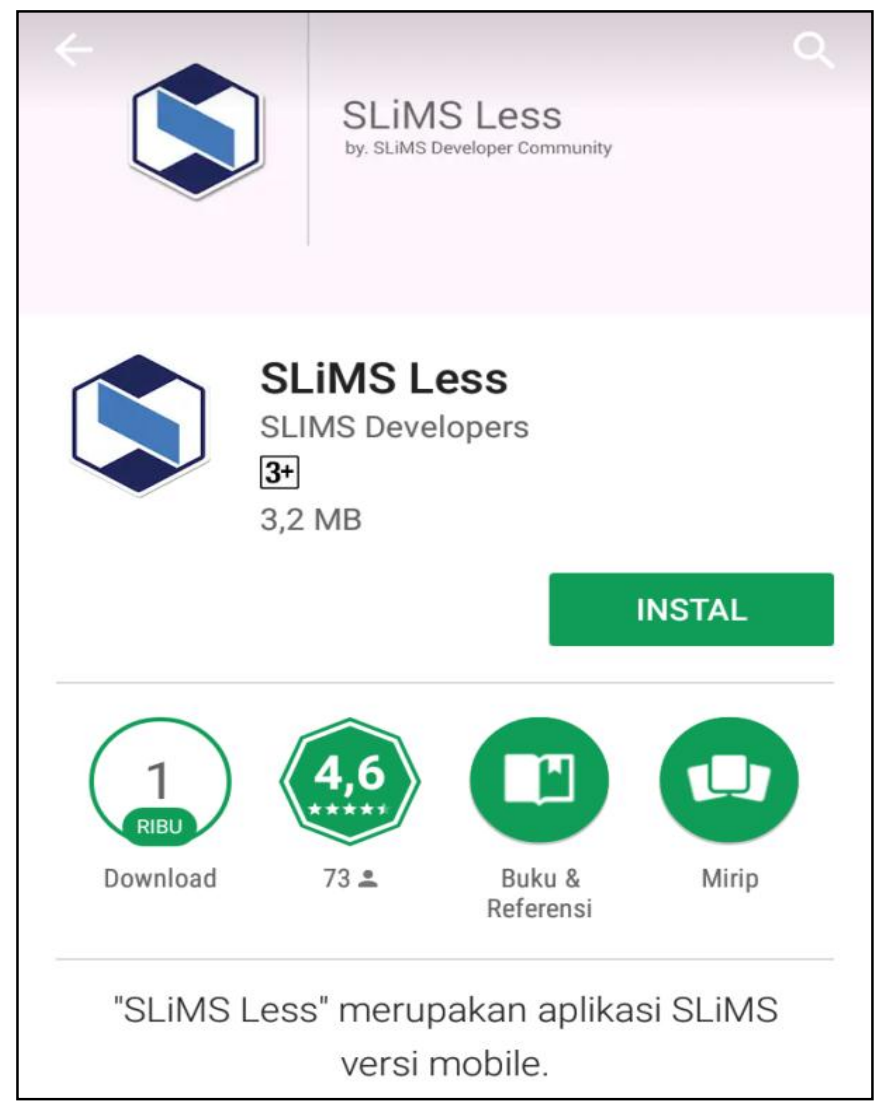

Sumber: Data primer diolah (2018)

Gambar 6. Otomasi Perpustakaan Berbasis Mobile SLiMS: "SLiMS Less" 


\subsection{Indikator Pencapaian dan Tolak Ukurnya}

Berdasarkan pembahasan di atas maka didapatkan hasil realisasi capaian (Tabel 4).

Tabel 4. Indikator Pencapaian dan Tolak Ukurnya

\begin{tabular}{lllll}
\hline No & Indikator & $\begin{array}{l}\text { Tolak Ukur } \\
\text { Pencapaian }\end{array}$ & $\begin{array}{l}\text { Target } \\
\text { Capaian }\end{array}$ & $\begin{array}{l}\text { Realisasi } \\
\text { Capaian }\end{array}$ \\
\hline 1 & $\begin{array}{l}\text { Peserta mampu menguraikan berbagai strategi } \\
\text { peningkatan membaca di keluarga }\end{array}$ & Non Tes & $75 \%$ & $100 \%$ \\
2 & $\begin{array}{l}\text { Peserta mampu mengerjakan soal uji tes klas- } \\
\text { ifikasi bahan pustaka secara sederhana }\end{array}$ & $\begin{array}{l}\text { Tes Uji Ke- } \\
\text { mampuan }\end{array}$ & $75 \%$ & $80 \%$ \\
3 & $\begin{array}{l}\text { Peserta mampu merumuskan ide desain dan } \\
\text { Tata Ruang Perpustakaan Keluarga yang } \\
\text { sesuai dengan kondisi di masing-masing } \\
\text { keluarga }\end{array}$ & $\begin{array}{l}\text { Tes Uji Ke- } \\
\text { mampuan }\end{array}$ & $80 \%$ & $98 \%$ \\
4 & $\begin{array}{l}\text { Peserta mampu menjelaskan pentingnya pem- } \\
\text { anfaatan teknologi informasi dalam mengel- } \\
\text { ola pepustakaan keluarga. }\end{array}$ & $\begin{array}{l}\text { Tes Uji Ke- } \\
\text { mampuan }\end{array}$ & $80 \%$ & $93 \%$ \\
& & & \\
& & &
\end{tabular}

Sumber: Data primer diolah (2018)

Salah satu indikator keberhasilan lainnya dari kegiatan pengabdian adalah adanya kepuasan dari para pengguna atau peserta kegiatan. Untuk mendapatkan respon dan bahan evaluasi dari para peserta, di akhir kegiatan, para peserta diberikan kesempatan memberikan pesan dan kesan terhadap kegiatan pengabdian. Berikut ini merupakan pesan dan kesan dari para peserta yang telah diringkas diantaranya adalah : (a) seminar bagus dan bermanfaat, (b) sangat menarik untuk membuat perpustakaan dirumah, (c) sangat baik, (d) menambah pengetahuan, (e) ditambah dengan praktik (f) diperbanyak materi minat baca, (g) terus semangat membaca buku, (h) informatif dan memotivasi, (i) lebih sering diadakan seminar, (j) memanfaatkan teknologi, (k) terus mengajak masyarakat.

Secara umum seluruh peserta memberikan respon yang sangat positif terhadap kegiatan pengabdian yang membahas tentang pengelolaan perpustakaan keluarga. Beberapa masukan yang berarti terkait teknis kegiatan akan menjadi bahan evaluasi dan 
perbaikan bagi kegiatan serupa yang akan dilaksanakan pada masa mendatang bagi masyarakat ataupun komunitas lain.

\section{KESIMPULAN DAN SARAN}

Secara umum seluruh peserta memberikan respon positif terhadap kegiatan tersebut. Kegiatan memiliki kompetensi penguasaan materi yang baik, interaktif, menarik, dan memberi kesempatan berdiskusi. Selain itu, 95\% peserta menjawab pelatihan yang diberikan bermanfaat dan $98 \%$ peserta menjawab materi pelatihan ini relevan dengan kebutuhan peserta. Hal ini menjadi landasan bagi pelaksana kegiatan pengabdian bahwa masyarakat memerlukan edukasi tentang pengelolaan perpustakaan keluarga.

Merujuk pada masukan dari para peserta yang menginginkan untuk memperdalam kembali tentang pemanfaatan teknologi informasi (SLiMS) dalam pengelolaan perpustakaan keluarga, maka pada tahap pengabdian kepada masyarakat selanjutnya, akan diberikan pendalaman materi tentang pemanfaatan SLiMS dalam mengelola perpustakaan keluarga yang lebih intensif dan aplikatif.

\section{UCAPAN TERIMAKASIH}

Ucapan terima kasih terhadap pihak Universitas YARSI khususnya Lembaga Pengabdian kepada Masyarakat (LPM UY) yang telah memfasilitasi terselenggaranya kegiatan pengabdian ini berjalan dengan baik. 
DAFTAR PUSTAKA

Baker, L., Scher, D., \& Mackler, K. (1997). Home and Family Influences On Motivation for Reading. Educational Psychologist, 69-82. https:// www.researchgate.net/profile/Linda_Baker6/publication/240240898_Ho me_and_Family_Influences_on_Motivations_for_Reading/links/0f3175367f9d6 15bb9000000.pdf

Bano, J., Jabeen, Z., \& Qutoshi, S. B. (2018). Perceptions of Teachers about the Role of Parents in Developing Reading Habits of Children to Improve their Academic Performance in Schools. Journal of Education and Educational Developement, 42-59. https://files.eric.ed.gov/fulltext/EJ1180618.pdf

Chen, S.-Y. (2008). Who Is the Avid Adolescent Reader in Taiwan? The Role of Gender, Family, and Teacher. Journal of Adolescent \& Adult Literacy, 216-223. : http://web.ba.ntu.edu.tw/luolu/RI\%20201212.pdf

Farida, I. (2001). Peran Keluarga Dalam menumbuhkan Minat Baca Anak . AlMaktabah,149-156.http://journal.uinjkt.ac.id/index.php/almaktabah/article/view/1647

Huriyah, L. (2016). Peran Perpustakaan Keluarga Dalam Meningkatkan Minat Dan Keterampilan Membaca Anak . Journal of Islamic Education Studies , 70-95. http://joies.uinsby.ac.id/index.php/joies/article/download/4/3/

Santoso, H. (2011, April). Perpustakaan Keluarga Sebagai Media Membangun Minat Baca. Retrieved from http://library.um.ac.id/index.php/ArtikelPustakawan/perpustakaan-keluarga-sebagai-media-pembinaan-minat-danbudaya-baca.html 